\title{
Dietary profile and nutritional status of climacteric women
}

\author{
Vanessa Huber Idalencio ${ }^{1 *}$, Francieli Aline Conte' ${ }^{1}$ Ligia Beatriz Bento Franz ${ }^{1}$ \\ 'Universidade Regional do Noroeste do Estado do Rio Grande do Sul (UNIJUí), Ijuí, RS, Brazil
}

\section{Abstract}

Objective: To identify the dietary profile and nutritional status of climacteric women, and the relationship between these two spheres. Methods: A cross-sectional study with 140 women between 35 and 65 years old, examined about dietary patterns and nutritional status and later analysis of the relationship between diet classification and body mass index, waist circumference, and body fat percentage. Results: The dietary pattern presented a median score, related to nutritional status of overweight and obesity, high or very high waist circumference, and percentages of high or very high fat mass; statistical association between dietary pattern classification and body mass index as well as waist circumference was found. No statistical association was found between the classification of diet and the percentage of body fat. Conclusions: These data reinforce the need for continuity of the project to elucidate the phenomenon of menopause and identify the potential risks arising from the aging process related to the climacteric.

Keywords: climacteric; nutritional status; feeding.

\section{Introduction}

The majority of Brazil population is composed by women, who are the main users of the Brazilian public health system (Sistema Único de Saúde - SUS). This emphasize the importance of women's health evaluation, in the reproductive age as well as in the climacteric period, when hormonal changes occur, affecting physiological, aesthetic and even physical aspects, due to the decrease in the estrogen hormone production (hypoestrogenism). ${ }^{1}$

Vasomotor symptoms as hot flashes and menstrual irregularities are the main symptoms of menopause, although conditions such as cardiovascular disease (CVD), depression and cognitive dysfunction are also common in the period. ${ }^{2}$ Perimenopausal women report an increased psychological and physiological symptoms, followed by a relative decrease in the postmenopausal period, specially depressive symptoms. ${ }^{3}$

Menopause period is associated with an increase in body weight, higher deposition of fat in the abdominal region with an increase in the risk of CVD, modification of body fat distribution and reduction of energy expenditure. ${ }^{4}$ Transient hormonal, psychic and physical changes, coupled with the emotional stress that the period may imply, can negatively impact women's health and life quality. ${ }^{5}$

An adequate diet can reduce the risk of death from chronic diseases, so feeding has various meanings, both psychological and physiological. ${ }^{6}$ Moreover, an suitable diet also assists in the prevention and treatment of obesity, especially when combined with physical activity, which is greatly reduced at this stage of life. ${ }^{7}$

Changes in body composition may be related to socioeconomic factors, use of medications, incidence of climacteric symptoms, hyper- or hypocaloric diets. ${ }^{8}$ Based on these considerations, this study aimed to identify the dietary pattern, nutritional status and the relationship between these aspects, in women in the climacteric period.

\author{
Financial support: VHI has a PIBIC/CNPq scholarship. \\ Conflicts of interest: The authors declare no conflicts of interest. \\ Submitted: August 23, 2017. \\ Accepted: November 21, 2017. \\ Study carried out at Regional University of the Northwest of the State of Rio Grande do Sul (UNIJUí), ljuí, RS, Brazil.
}

Copyright Idalencio et al. This is an Open Access article distributed under the terms of the Creative Commons Attribution License, which permits unrestricted use, distribution, and reproduction in any medium, provided the original work is properly cited. 


\section{Materials and methods}

\section{Study design}

A cross-sectional study was conducted during a 5 year project called "Female Aging Study" (2014) from Research Group on Human Aging (GERON) from Universidade Regional do Noroeste do Estado do Rio Grande do Sul (UNIJUí) and approved by local institutional review board (number 864.988).

\section{Patients}

There was 301 registered women at a Family Health Strategy program (ESF) in November 2016. The exclusion criteria were: women with cancer or in chemotherapeutic/radiotherapeutic treatment, pregnant women, women with incomplete data in the database (incomplete data from the general health and / or dietary questionnaire) or who did not carry out nutritional status assessment, totaling 161 exclusions and resulting in 140 analyzed women. These women were interviewed regarding dietary patterns (food frequency questionnaire), nutritional status (body mass index, waist circumference, and body fat percentage), and social demographic information.

\section{Measures and data}

The stature was measured using a Sanny ${ }^{\circledR}$ Personal Portable stadiometer; the body weight was verified by digital Camry ${ }^{\circledR}$ digital scale (with capacity of $150 \mathrm{Kg}$ ) and from these two measures the body mass index was calculated (BMI).

The abdominal perimeter evaluation was performed in the orthostatic position, with a relaxed abdomen, with anthropometric positioning in the horizontal at the natural waist level (narrower part of the trunk); the evaluation of the body composition was made by bioelectrical impedance analysis (BIA), with the aid of the OMRON® brand bipolar portable device. The anthropometric evaluation followed the recommendations and guidelines of the Food and Nutrition Surveillance System (SISVAN) of the Brazilian Ministry of Health. ${ }^{9}$

$\mathrm{BMI}$ and waist circumference (WC) were classified according to the parameters of the World Health Organization; ${ }^{10}$ the BMI, from 60 years old, was classified according to The Nutrition Screening Initiative (NSI). ${ }^{11}$ The body composition characteristic was measured and classified by the equipment manual itself. ${ }^{12}$

The evaluation of dietary habits was carried out following the protocol of the questionnaire "How is your diet" of the Food Guide for the Brazilian Population of 2006, ${ }^{13}$ which evaluates the food consumption by assigning, in the end, a score and classification: "Up to 28 points", " 29 to 42 points "and" 43 points or more ". In this scale, the higher the number of points, the more positive the result.

\section{Statistical analysis}

Data were evaluated in the Statistical Program for Social Sciences (SPSS), version 18.0. A normality test of Komogorov-Smirnov for each variable was used. Descriptive statistics was done (frequency, mean and standard deviation) was done for nutritional status and food consumption variables. Statistics analysis for association between variables was done using the Pearson Chi-square test.

\section{Results}

A total of 140 women were evaluated, with a mean age of 51.64 years \pm 7.55 years, ranging from 36 to 65 years. As a result of the nutritional assessment and dietary profile, a mean BMI of $29.5 \mathrm{Kg} / \mathrm{m}^{2} \pm 5.7 \mathrm{Kg} / \mathrm{m}^{2}$, with a minimum of $17,0 \mathrm{Kg} / \mathrm{m}^{2}$ and a maximum of $52,8 \mathrm{Kg} / \mathrm{m}^{2}$. The mean result for the WC was $91.3 \mathrm{~cm} \pm 12.1 \mathrm{~cm}$, with a minimum of $59.0 \mathrm{~cm}$ and a maximum of $139.0 \mathrm{~cm}$. Regarding the percentage of fat mass (PFM), an average of $37.2 \% \pm 5.8 \%$ of body fat was observed, with a minimum percentage of $14.4 \%$ and a maximum of $49.0 \%$.

Nutrition score was 34.5 points \pm 6.2 points, with a minimum score of 15 and a maximum of 51 points. Considering the classification as a growing scale of points, where the food quality increases as the score increases, this result can be considered a reasonable food.

The BMI revealed high rates of overweight and obesity (I, II and III) among adult and elderly women, accounting for $76.5 \%$ of the participants. In the eutrophic interval, there were $22 \%$ of the interviewed women, while two of the participants (1.4\%) were underweight.

Regarding WC, $57.8 \%$ of the women showed a very high WC and $26.4 \%$ a high WC, in a total of 118 women.

The PFM evaluation showed a high number of women classified as high or very high PFM, comprising $69.6 \%$ of the participants $(n=94)$. 
The food score classification according to the "How is your diet" questionnaire allowed us that $76.4 \%$ of the women had 29 to 42 points. The lowest percentage of women were those that obtained the best scores - "43 points or more", totaling $9.3 \%$ of the participants. As a consequence, $14.3 \%$ of the women had a score of "up to 28 points", with the lowest scores.

The relationship between diet and nutritional status was verified through data crossing, allowing the identification of a greater concentration of results between 29 and 42 points (median score), mainly among eutrophic women. More than a half of the interviewed women were overweight or obese I women, as shown in Table 1.

The combined results of the PC and the food classification revealed a higher concentration of women with food classified between 29 and 42 points, with very high WC, as seen in Table 2.

The mixed combined of the PFM evaluation and the food classification also showed results close to the high and very high percentages of PFM, and food classified between 29 and 42 points, which can be observed in Table 3 .

Table 1. Association of the Body Mass Index with the Food Classification. Ijuí/RS, 2016

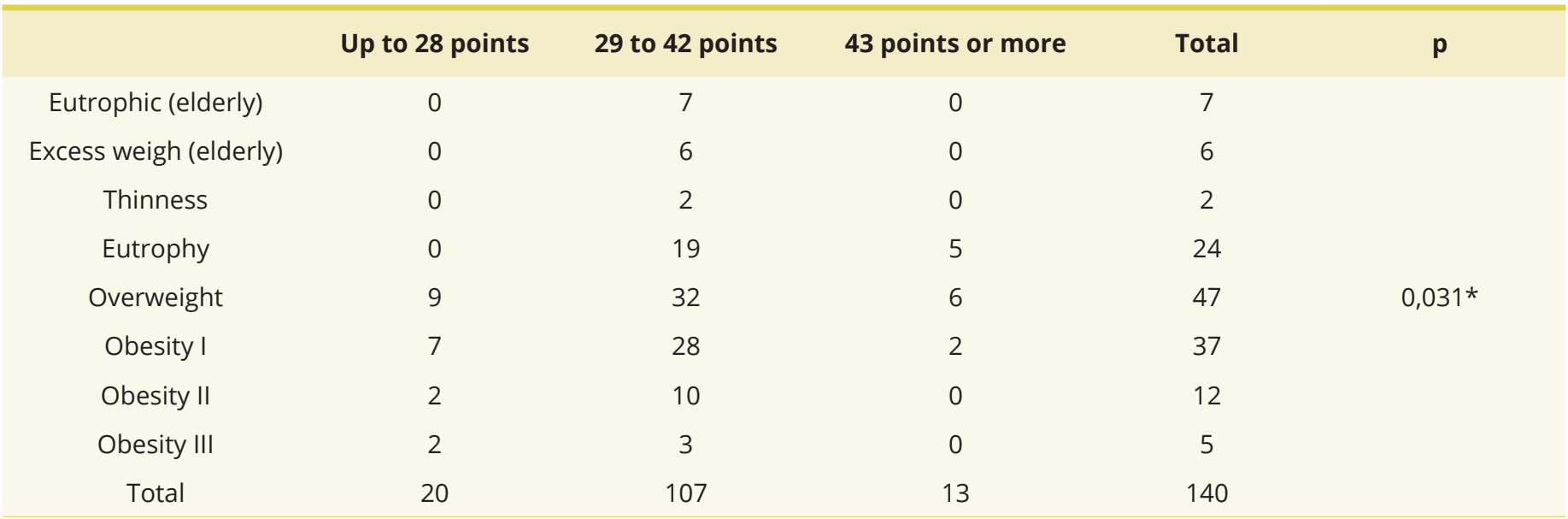

Pearson's Chi-square test; *statistically significant, with reliability $<95 \%$.

Table 2. Relation of Waist Perimeter with Feed Classification. Ijuí/RS, 2016

$\begin{array}{cccccc} & \text { Up to } \mathbf{2 8} \text { points } & \mathbf{2 9} \text { to } \mathbf{4 2} \text { points } & \mathbf{4 3} \text { points or more } & \text { Total } & \mathbf{2} \\ \text { Normal } & 1 & 18 & 3 & 37 & 0,020^{*} \\ \text { High } & 4 & 30 & 59 & 7 & 81 \\ \text { Very High } & 15 & 107 & 13 & 140\end{array}$

Pearson's Chi-square test; *statistically significant, with reliability $<95 \%$.

Table 3. Association of Body Fat Percentage with Food Rating. Ijuí/RS, 2016

\begin{tabular}{|c|c|c|c|c|c|}
\hline & Up to 28 points & 29 to 42 points & 43 points or more & Total & $\mathbf{P}$ \\
\hline Low & 0 & 1 & 1 & 2 & \multirow{6}{*}{0,280} \\
\hline Recommended & 3 & 33 & 3 & 39 & \\
\hline High & 8 & 35 & 6 & 49 & \\
\hline Very high & 7 & 35 & 3 & 45 & \\
\hline Missing & 2 & 3 & 0 & 5 & \\
\hline Total & 20 & 107 & 13 & 140 & \\
\hline
\end{tabular}

Pearson's Chi-Square Test. 
General results regarding nutritional status and the food classification displayed a relationship between the classification of the food profile and BMI, that is, women who obtained lower scores of food profile also presented a higher BMI $(p=0.031)$. There was also an association between the WC classification and the food classification $(p=0.02)$. However, there was no statistical association between the dietary profile and PFM. Therefore, there was an inverse relationship between feeding and the nutritional status of women through BMI and WC.

\section{Discussion}

A menopause syndrome can result in vasomotor symptoms, sleep and mood disorders, osteoporosis, CVD, neurodegenerative diseases, oxidative damage, and others symptoms.$^{14} \mathrm{~A}$ diet rich in antioxidants, could prevent the accumulation of these damage.

The nutritional status and body composition evaluation are important for the identification of CVD risk, such as dyslipidemia, hypertension, diabetes, breast cancer ${ }^{15}$ and other diseases.

We observed a mean BMI of $29.5 \mathrm{Kg} / \mathrm{m}^{2}$ among analyzed women, with a classification of overweight and obesity (I, II and III) in 76.5\% of them. In a study conducted in Passo Fundo, Rio Grande do Sul, Brazil, the mean BMI of climacteric women was similar to this present study (mean BMI of $28.3 \mathrm{Kg} / \mathrm{m}^{2} \pm 7.0 \mathrm{Kg} / \mathrm{m}^{2}$ ), ${ }^{16}$ as well as a UNESP study (mean BMI for women $<50$ years $\left.29.9 \mathrm{Kg} / \mathrm{m}^{2} \pm 7.2 \mathrm{Kg} / \mathrm{m}^{2}\right) .{ }^{17}$

In a group of climateric women from Montes Claros, Minas Gerais - Brazil, the mean BMI was $28.1 \mathrm{Kg} / \mathrm{m}^{2} \pm 5.6 \mathrm{Kg} / \mathrm{m}^{2}$; and $34 \%$ were classified as eutrophic, $30.8 \%$ were overweight and $35.2 \%$ were obese. $^{8}$

Elevated body mass indexes are related to the onset of CVD and degenerative diseases, especially among women with a $\mathrm{BMI} \geq 30 \mathrm{~kg} / \mathrm{m}^{2}$, independently of climacteric phase. ${ }^{18}$

Regarding the WC evaluation, the mean value was $91.3 \mathrm{~cm} \pm 12.1 \mathrm{~cm}$, considered elevated or very high. Similar results were found in a study carried out in Passo Fundo $(91.3 \mathrm{~cm} \pm 13,7 \mathrm{~cm}) \cdot{ }^{19} \mathrm{In}$ another study, at Feira de Santana, Bahia, Brazil, an average of $84.65 \mathrm{~cm} \pm 10.57 \mathrm{~cm}$ was observed for WC. ${ }^{20}$

The PFM averages were considered high and very high for $69.6 \%$ of the evaluated women, with an average value of $37.2 \% \pm 5.8 \%$. Buonani et al. ${ }^{17}$ showed an average PFM score of $45.1 \% \pm 5.5 \%$, and in a part of the PONS Study, the average adiposity was $34.1 \% \pm 6.7 \%$ for pre-menopausal women and $36.2 \% \pm 6.5 \%$ for postmenopausal women. ${ }^{21}$

The observed food profile had a reasonable quality, with a mean score of $34.5 \pm 6.2$ points. No updated references were found for the questionnaire "How is your diet?", but in an evaluation of the food consumption pattern of climacteric women in southern Brazil, it was possible to notice a food pattern among climacteric phases, with prevalence of traditional food and culinary preparations, ${ }^{22}$ in agreement with Food Guide recommendation. ${ }^{23}$

A previous study with 215 postmenopausal women concluded that $82.8 \%$ of the women consumed a diet classified as "needs improvements" and $16.3 \%$ consumed a "poor" quality diet, resulting in a percentage of only $0.9 \%$ consuming an "adequate" diet. ${ }^{24}$ Diet quality may be associated with higher quality of life and lower risk of developing diseases, such as CVD.

The quality of diet is related to cardiovascular risk, since women with higher consumption of Mediterranean diet consumed larger quantities of fruits, vegetables and nuts, whole grains and fish, as well as smaller amounts of red or processed meat, poultry and meat with high lipid concentration. Women who consumed the Dietary Approaches to Stop Hypertension (DASH) had a similar consumption to the Mediterranean, but less consumption of sugary drinks. ${ }^{25}$ Relative to fruits and vegetables consumption, a part from the PONS Study showed that premenopausal and and postmenopausal period women, used to consume similar portions (4.06 \pm 1.71 servings/day for premenopausal and $4.07 \pm 1.71$ portions / day for postmenopausal women). ${ }^{21}$

Diet quality has implications on the health of menopausal women, and is related to several factors. In an American study, when evaluating the relationship between diet and optimism, healthy eating indexes had an inverse association with BMI, WC, history of diabetes or hypertension and depression. ${ }^{26}$

\section{Conclusion}

The mean BMI of the 140 evaluated women was $29.5 \mathrm{Kg} / \mathrm{m}^{2}$, similar to other previous results. Mean WC was very high $(91.3 \mathrm{~cm})$, suggesting a high risk of developing CVD. The high PBF (37.2\%) is related to bone loss along with abdominal obesity. When analyzing the food profile, the average score was 34.6 points, classified as reasonable, suggesting the need for improvements.

This moderate food profile had a significant impact on the BMI, WC and PFM, since "between 29 and 42 points" was higher in BMI of overweight and obesity $(n=60)$, high or very high WC ( $n=89 ; 70)$, showing an association between BMI $(p=0.031)$ and WC $(p=0.02)$ with the quality of diet. 
Our results reinforces the need for continuity of this project, with the data classification in the respective phases of the climacteric in order to elucidate the phenomenon of menopause and its intercurrences. It is imperative to provide health education and nutritional intervention through dietary guidelines, aiming the improvement of health indicators.

\section{References}

1. Brasil. Ministério da Saúde. Secretaria de Atenção à Saúde. Departamento de Ações Programáticas Estratégicas. Manual de Atenção à Mulher no Climatério/Menopausa. Brasília: Editora do Ministério da Saúde, 2008; 192 p. (Série A. Normas e Manuais Técnicos) (Série Direitos Sexuais e Direitos Reprodutivos - Caderno, n. 9).

2. TAKAHASHI TA, JOHNSON KM. Menopause. Med Clin North Am. 2015;99(3):521-34. PMid:25841598. http://dx.doi.org/10.1016/j. mcna.2015.01.006.

3. BORKOLES E, REYNOLDS N, THOMPSON DR, SKI CF, STOJANOVSKA L, POLMAN RC. The role of depressive symptomathology in peri and post menopause. Maturitas. 2015;81(2):306-10. PMid:25857280. http://dx.doi.org/10.1016/j.maturitas.2015.03.007.

4. Sociedade Norte-Americana de Menopausa. Guia da menopausa. 7. ed. Pepper Pike: NAMS; 2012. 89 p. Traduzido pela SOBRAC.

5. BOTELL L. Climaterio, daño vascular y sexualidad. Rev Cuba Obstet Ginecol. 2013;39:413-26.

6. GEORGE SM, BARBASH RB, MANSON JE, REEDY J, SHIKANY JM, SUBAR AF, et al. Comparing indices of diet quality with chronic disease mortality risk in postmenopausal women in the women's health initiative observational study: evidence to inform national dietary guidance. Am J Epidemiol. 2014;180(6):616-25. PMid:25035143. http://dx.doi.org/10.1093/aje/kwu173.

7. CARVALHO ED, VALADARES ALR, COSTA-PAIVA LH, PEDRO AO, MORAIS SS, PINTO-NETO AM. Atividade física e qualidade de vida em mulheres com 60 anos ou mais: fatores associados. Rev Bras Ginecol Obstet. 2010;32(9):433-40. PMid:21271148. http:// dx.doi.org/10.1590/S0100-72032010000900004.

8. Gonçalves JTT, Silveira MF, Campos MCC, Costa, MHR. Overweight and obesity and factors associated with menopause. Ciênc Saúde Coletiva. 2016;21:1145-1156.

9. Brasil Ministério da Saúde. Secretaria de Atenção à Saúde, Departamento de Atenção Básica. Orientações para a coleta e análise de dados antropométricos em serviços de saúde: Norma Técnica do Sistema de Vigilância Alimentar e Nutricional - SISVAN. Brasília: Ministério da Saúde, 2011. 76 p. (Série G. Estatística e Informação em Saúde).

10. World Health Organization. Obesity: preventing and managing the global epidemic. Geneva: WHO, 2000. (WHO Technical Report Series, 894).

11. The Nutrition Screening Initiative. Incorporating nutrition screening and interventions into medicalpractice: a monograph for physicians. Washington: American Academy of Family Physicians, The American Dietetic Association, National Council on Aging Inc., 1994.

12. GALLAGHER D, HEYMSFIELD SB, MOONSEONG H, JEBB SA, MURGATROYD PR, SAKAMOTO Y. Healthy percentage body fat ranges: an approach for developingguidelines based on body mass index. Am J Clin Nutr. 2000;72(3):694-701. PMid:10966886.

13. Brasil. Ministério da Saúde. Secretaria de Políticas de Saúde. Como está sua alimentação? Brasília: Ministério da Saúde; 2007 [cited 2016 Nov 18]. Available from: http://www.saude.gov.br.

14. CERVELLATI C, BERGAMINI CM. Oxidative damage and the pathogenesis ofmenopause related disturbances and diseases. Clin Chem Lab Med. 2016;54(5):739-53. PMid:26544103. http://dx.doi.org/10.1515/cclm-2015-0807.

15. FILHO JFL, BACCARO LFC, FERNANDES T, CONDE DM, COSTA-PAIVA L, PINTO NO AM. Epidemiologia da menopausa e dos sintomasclimatéricos em mulheres de uma regiãometropolitana no sudeste do Brasil: inquérito populacional domiciliar. Rev Bras Ginecol Obstet. 2015;37(4):152-8. PMid:25992497. http://dx.doi.org/10.1590/S0100-720320150005282.

16. COLPANI V, SPRITZER PM, LODI AP, DORIGO GG, MIRANDA IAS, HAHN LB, et al. Atividade física de mulheresno climatério: comparaçãoentre auto-relato e pedômetro. Rev Saude Publica. 2014;48(2):258-65. PMid:24897047. http://dx.doi.org/10.1590/ S0034-8910.2014048004765.

17. BUONANI C, ROSA CSC, DINIZ TA, CHRISTOFARO DG, MONTEIRO HL, ROSSI FE, et al. Physical activity and body composition in menopausal women. Rev Bras Ginecol Obstet. 2013;35(4):153-8. PMid:23752579. http://dx.doi.org/10.1590/ S0100-72032013000400004.

18. MENZEL J, GIUSEPPE RD, WIENTZEK A, KROKE A, BOEING H, WEIKERT CE. Physical activity, bone health, and obesity in peri-/ preand postmenopausal women: results from the EPIC-potsdam study. Calcif Tissue Int. 2015;97(4):376-84. PMid:26108649. http://dx.doi.org/10.1007/s00223-015-0027-0.

19. COLPANI V, SPRITZER PM, LODI AP, DORIGO GG, MIRANDA IAS, HAHN LB, et al. Atividadefísica de mulheres no climatério: comparação entre auto-relato e pedômetro. Rev Saude Publica. 2014;48(2):258-65. PMid:24897047. http://dx.doi.org/10.1590/ S0034-8910.2014048004765.

20. ALMEIDA RT, ALMEIDA MMG, ARAUJO TM. Obesidade abdominal e risco cardiovascular: desempenho de indicadores antropométricos em mulheres. Arq Bras Cardiol. 2009;92(5):375-80. http://dx.doi.org/10.1590/\$0066-782X2009000500007.

21. SULIGA E, KOZIEL D, CIESLA E, RĘBAK D, GŁUSZEK S. Factors associated with adiposity, lipid profile disorders and the metabolic syndrome occurrence in premenopausal and postmenopausal women. PLoS One. 2016;11(4):1-19. PMid:27128677. http://dx.doi. org/10.1371/journal.pone.0154511. 
22. HOFFMANN M, MENDES KG, KANUTO R, GARCEZ AS, RODRIGUES AD, OLINTO MTA. Dietary patterns in menopausal women receiving outpatient care in Southern Brazil. Ciênc Saúde Coletiva. 2015; 20: 1565-1574.

23. Brasil. Ministério da Saúde. Secretaria de Atenção à Saúde. Departamento de Atenção Básica. Guia alimentar para a população brasileira. Brasília: Ministério da Saúde; 2014.

24. VENTURA DA, FONSECA VM, RAMOS EG, MARINHEIRO LP, SOUZA RA, CHAVES CR, et al. Association between quality of the diet and cardiometabolic risk factors in postmenopausal women. Nutr J. 2014;13(1):121. PMid:25529573. http://dx.doi. org/10.1186/1475-2891-13-121.

25. BERTOIA ML, TRICHE EW, MICHAUD DS, BAYLIN A, HOGAN JW, NEUHOUSER ML, et al. Mediterranean and Dietary Approaches to Stop Hypertension dietary patterns and risk of sudden cardiac death in postmenopausal women. Am J Clin Nutr. 2014;99(2):34451. PMid:24351877. http://dx.doi.org/10.3945/ajen.112.056135.

26. HINGLE MD, WERTHEIM BC, TINDLE HA, TINKER L, SEGUIN RA, ROSAL MC, et al. Optimism and diet quality in the Women's Health Initiative. J Acad Nutr Diet. 2014;114(7):1036-45. PMid:24556429. http://dx.doi.org/10.1016/j.jand.2013.12.018.

\section{*Correspondence}

Vanessa Huber Idalencio

Universidade de Passo Fundo (UPF)

Rua Paissandu, 1455, ap. 402, Centro

CEP 99010-101, Passo Fundo, RS, Brazil

Tel.: +55 (55) 9 9106-4908

E-mail: vanessa.idalencio@hotmail.com

\section{Authors information}

VHI - Nutritionist; Multiprofessional Resident Professional in Health of the Elderly, Universidade de Passo Fundo (UPF). FAC - Nutritionist; Master's Degree in Integral Health Care, Universidade Regional do Noroeste do Estado do Rio Grande do Sul. LBBF - Nutritionist; PhD in Public Health, Universidade Regional do Noroeste do Estado do Rio Grande do Sul.

\section{Authors contribution}

VHI: He wrote the manuscript in all its stages. FAC: Contributed to the accomplishment of the statistical analyzes and interpretation of the data, part of the writing and formatting and normalization of the article for submission to the magazine. LBBF: Contributed in all stages of the process: project orientation, writing, reading and correction of the article. 